\title{
Comparative Characteristics of Anti-depressant, Anti-hypoxic Action, and Effect on the Physical Endurance of Scutellaria baicalensis Drugs
}

\section{Scutellaria baicalensis (Çin Takkesi) İlaçlarının Anti-Depresan, Anti-Hipoksik ve Fiziksel Dayanıklııı Üzerine Etkilerinin Karşılaştırmalı Özellikleri}

\author{
(D) Anatolii MATVIYCHUK, (D) Galina SLIPCHENKO*, (D) Yurii STOLETOV, (D) Galina BELIK, (D) Olena RUBAN, (D) Sergii KUTSENKO \\ National University of Pharmacy, Department of Industrial Technology of Drugs, Kharkov, Ukraine
}

\begin{abstract}
Objectives: The influence of original drugs from Scutellaria baicalensis (SB) Georgi (dry extract, powder of rhizomes and roots, tablets "Scutex" on the basis of the dry extract and capsules "Scutella", which contain powder of rhizomes with roots) was studied on depressive behavior, physical endurance and anti-hypoxic activity in mice.

Materials and Methods: The used dry extract SB (SBDE), powder of roots and rhizomes from SB (SBRP), tablets from dry extract of SB named "Scutex", and hard gelatin capsules from the crushed root of SB named "Scutella" were obtained from National University of Pharmacy, Department of Industrial Technology of Drugs. In the experiment, 94 random-breed white male mice weighing 20-29 g were used and kept in standard sanitary and laboratory conditions.

Results: The experiments revealed that SBDE had anti-depressant action. Powder from rhizomes and roots of SB and "Scutella" capsules had anti-hypoxic action. All test drugs showed no influence on the physical endurance of mice. These results suggest the possible use of SBDE as an anti-depressant drug, and rhizomes with roots and "Scutella" capsules as an anti-hypoxic remedy.

Conclusion: SBDE at a dose $50 \mathrm{mg} / \mathrm{kg}$ shows anti-depressant activity that exceeds the activity of the comparison drug "Bilobil". SBDE, SBRP, "Scutex" tablets and "Scutella" capsules do not affect the physical endurance of mice. SBDE at a dose $50 \mathrm{mg} / \mathrm{kg}$ and SBRP at a dose of $173 \mathrm{mg} /$ $\mathrm{kg}$ and $260 \mathrm{mg} / \mathrm{kg}$ exhibit anti-hypoxic activity. "Scutex" tablets show no anti-hypoxic action and "Scutella" capsules cause probable anti-hypoxic action that exceeds the effect of the reference drug "Bilobil".
\end{abstract}

Key words: Scutellaria baicalensis, anti-depressive action, physical endurance, anti-hypoxic activity

ÖZ

Amaç: Orijinal Scutellaria baicalensis (SB) Georgi ilaçlarının (kuru ekstresi, rizom ve kök tozları, kuru ekstre bileşimli "Scutex" tabletleri ve rizom ve kök tozu taşıyan "Scutella" kapsülleri) depresif davranış, fiziksel dayanıklılık ve anti-hipoksik aktivite üzerine etkisi sıçanlar üzerinde test edilmiştir. Deneyler, SB'nin kuru ekstresinin anti-depresan etkiye sahip olduğunu ortaya koymuștur.

Gereç ve Yöntemler: SB kuru ekstresi (SBDE), SB köklerinden (SBRP) ve rizomlarından elde edilen toz, “Scutex” kodlu SB'nin kuru ekstresinden elde edilen tabletler ve "Scutella" kodlu SB'nin ezilmiş kökünden elde edilen sert jelatin kapsüller, Ulusal Eczacılık Üniversitesi, İlaçların Endüstriyel Teknolojisi Anabilim Dalı'nda hazırlandı. Deneyde 20-29 g ağırlığındaki, rastgele-ırk, beyaz erkek sıçanlar kullanıldı ve standart sağlık ve laboratuvar koșullarında tutuldu.

Bulgular: Deneyler SB'nin kuru ekstresinin anti-depresan etkiye sahip olduğunu ortaya çıkarmıştır. SB rizom ve kök tozunun ve "Scutella" kapsüllerinin anti-hipoksik etkisi vardır. Test edilen ilaçlardan hiçbiri sıçanların fiziksel dayanıklılı̆ı üzerinde etki göstermemiştir. Bu sonuçlar, SB'nin kuru ekstresinin anti-depresan ilaç, kök, rizomlar ve "Scutella" kapsüllerinin anti-hipoksik ilaç olarak kullanımını önermektedir.

Sonuç: SBDE 50 mg/kg'lık bir dozda, karșılaștırma ilacı "Bilobil” etkisini așan anti-depresan aktivite gösterir. SBDE, SBRP, "Scutex" tabletleri ve "Scutella" kapsülleri sıçanların fiziksel dayanıklıığını etkilemez. SBDE, 50 mg/kg dozunda ve SBRP'de $173 \mathrm{mg} / \mathrm{kg}$ ve $260 \mathrm{mg} / \mathrm{kg}$ dozunda antihipoksik aktivite gösterir. "Scutex" tabletleri anti-hipoksik etki göstermez ve "Scutella" kapsülleri referans ilaç "Bilobil" etkisini aşan muhtemel anti-hipoksik etkilere neden olur.

Anahtar kelimeler: Scutellaria baicalensis, anti-depresan etki, fiziksel dayanıklıık, anti-hipoksik aktivite

*Correspondence: E-mail: galinaslipchenko@ukr.net, Phone: +380957355942 ORCID-ID: orcid.org/0000-0002-4783-7460

Received: 31.03.2017, Accepted: 05.10.2017

๑Turk J Pharm Sci, Published by Galenos Publishing House. 


\section{INTRODUCTION}

The creation of new effective drugs based on plant material is relevant and a priority direction of modern pharmacy. Herbal origin preparations have recently become very popular due to the variety of therapeutic effects provided by both individual substances and complex compounds found in plant material. Scutellaria baicalensis (SB) Georgi (Lamiaceae family) is a promising source of biologically active substances. The main biologically active substances of SB are flavonoids and flavonoid glycosides such as baicalin, baicalein, scutellarin, oroxylin, wogonin, apigenin, and others. In traditional Chinese medicine, roots of SB have long been used for hypertension, epilepsy, nervousness, sleep disorders. Recently, the psychotropic and cerebroprotective action of SB drugs has been investigated, including in neurodegenerative diseases, and CNS lesions of ischemic genesis. ${ }^{1-6}$ It has been proved that preparations of raw SB (dry extract, "Scutex" tablets and "Scutella" capsules) show anxiolytic and anti-amnestic effects. ${ }^{7.8}$ In view of the above, there is a need for the expediency of comprehensive comparative pharmacological studies of SB dry extract, powder of roots and rhizomes of SB and preparations based on them as potential psychotropic drugs. The purpose of the study was to evaluate the possible anti-depressant properties and antihypoxic action of the dry extract, powder of roots and rhizomes of SB and also "Scutex" tablets based on dry extract SB (SBDE) and hard gelatin capsules "Scutella", which contain powder of rhizomes with roots of SB, on the physical endurance of mice.

\section{MATERIALS AND METHODS}

The used SBDE, powder of roots and rhizomes from SB (SBRP), tablets from dry extract of SB named "Scutex", and hard gelatin capsules from the crushed root of SB named "Scutella" were obtained from National University of Pharmacy's Department of Industrial Technology of Drugs. In the experiment, 94 random-breed white male mice weighing 20-29 g were used and kept in standard sanitary and laboratory conditions. During the experiments, the animals were in the vivarium at $19-24^{\circ} \mathrm{C}$, humidity was under $50 \%$, the natural light mode was "daynight". The animals were housed in plastic cages and fed a standard diet. The experimental studies were performed in accordance with the "general ethical principles of animal experiments" (Ukraine, 2001) in accordance with the "European Convention for the Protection of vertebrate animals used for experimental and other scientific purposes". SBDE was used in doses of $25 \mathrm{mg} / \mathrm{kg}, 50 \mathrm{mg} / \mathrm{kg}, 75 \mathrm{mg} / \mathrm{kg}$; SBRP was used in doses of $87 \mathrm{mg} / \mathrm{kg}$ ( $25 \mathrm{mg} / \mathrm{kg}$ in terms of baicalin), $173 \mathrm{mg} /$ $\mathrm{kg}(50 \mathrm{mg} / \mathrm{kg}$ in terms of baicalin) and $260 \mathrm{mg} / \mathrm{kg}(75 \mathrm{mg} / \mathrm{kg}$ in terms of baicalin); "Scutex" tablets and "Scutella" hard gelatin capsules were used in doses of $320 \mathrm{mg} / \mathrm{kg}$ ( $50 \mathrm{mg} / \mathrm{kg}$ in terms of baicalin) and $260 \mathrm{mg} / \mathrm{kg}$ ( $75 \mathrm{mg} / \mathrm{kg}$ in terms of baicalin), respectively. SBDE, SBRP, crushed tablet mass "Scutex" and the contents of the "Scutella" capsules were dissolved in water and administered to the mice through intragastric probes in a volume of $0.1 \mathrm{~mL}$ for $10 \mathrm{~g}$ mass once per day for 5-8 days last 30-60 minutes before experiment. The control group was injected with the same amount of pooled tap water. The reference product-"Bilobil" (KRKA, Slovenia) at a dose of 100 $\mathrm{mg} / \mathrm{kg}$, was dissolved in water and injected in the same mode. ${ }^{9}$ All behavioral tests were conducted sequentially, synchronously with the appropriate control, because the effects depended on chronopharmacologic factor. The study of the anti-depressant properties of SBDE, SBRP, "Scutex" and "Scutella" drugs and reference drug were conducted using the mice tail suspension test (despair behavior)..$^{10}$ The anti-hypoxic effect was evaluated on the model of normobaric hypoxic hypoxia with hypercapnia." The impact of the studied substances on the physical endurance of mice was studied through a test of swimming with load. ${ }^{10}$

\section{Statistical analysis}

The results were examined statistically using STATISTICA 8.0 software by evaluating the reliability of differences between the comparison groups using Student's t parametric criterion in cases of normal distribution, nonparametric Mann-Whitney $U$ criterion in its absence. The difference was considered statistically significant at $p \leq 0.05$.

\section{RESULTS AND DISCUSSION}

Results of anti-depressant activity of SBDE in terms of the immobilization test (tail suspension test) are shown in Table 1. The obtained results indicate that SBDE at a dose of $50 \mathrm{mg} /$ $\mathrm{kg}$ increased latent time of frozen mice hanging 1.7 times or by $68 \%$ compared with control ( $p \leq 0.05$ ); amount of frozen hangs decreased 1.2 times or by $18 \%$; the overall duration of frozen hangs decreased 1.5 times or by $35 \%$ ( $p \leq 0.05$ ). The reference drug "Bilobil" in a dose of $100 \mathrm{mg} / \mathrm{kg}$ increased the latency time of frozen hangs 1.4 times or by $39 \%(p \leq 0.05)$, and total duration of frozen hangs tendentiously decreased 1.2 times. The action of SBDE exceeded the effect of the reference drug "Bilobil" 1.2 times by an increase in latency for frozen hangs. Therefore, SBDE possesses antidepressant action. The next step was to study the anti-depressant activity of SBRP in doses of 173 $\mathrm{mg} / \mathrm{kg}$ and $260 \mathrm{mg} / \mathrm{kg}$. SBRP in both doses had no significant effect on quantitative parameters of depressive behavior (Table 1). "Scutex" tablets and "Scutella" capsules also showed no probable anti-depressant activity (Table 1). They only biased the increased latent time of frozen hangs and reduced their total duration. On the other hand, the effect of the drug Ginkgo biloba ("Bilobil") on depressive behavior was weak and unstable, as in the different series of experiments it either increased latency time of immobilization or tendentiionally reduced its total duration, or had no significant effect. All drugs of SB; SBDE, SBRP, "Scutex" tablets, and "Scutella" capsules, as well as "Bilobil" had no effect on the physical endurance of mice in the test of swimming to exhaustion (Table 2). This was evidenced by the unchanged swimming time compared with the controls. Results of the study regarding the anti-hypoxic properties of SBDE in normobaric hypoxic hypoxia with hypercapnia model demonstrated an increased life expectancy of the mice of 1.3 times compared with the controls (Table 3 ), indicating a distinct anti-hypoxic effect of the drug. In the group of animals treated with the comparator, no statistically significant differences as compared with the controls were observed. SBRP at a dose 
Table 1. Influence of dry extract Scutellaria baicalensis and reference drug "Bilobil" on despair behavior in mice immobilization test conditions (tail suspension test)

\begin{tabular}{|c|c|c|c|}
\hline Group, dose, $n$ & Latent time of frozen hanging, $s$ & Number of frozen hangs & Total duration of frozen hangs, $s$ \\
\hline Control (1), $n=6$ & $42.8 \pm 3.70$ & $13.5 \pm 1.60$ & $108.7 \pm 7.00$ \\
\hline “Bilobil" 1, 100 mg/kg, n=6 & $59.5 \pm 5.70^{*}$ & $13.5 \pm 2.00$ & $93.3 \pm 6.00$ \\
\hline SBDE, $50 \mathrm{mg} / \mathrm{kg}, \mathrm{n}=9$ & $71.9 \pm 5.90 *$ & $11.1 \pm 2.00$ & $70.6 \pm 5.50^{*}$ \\
\hline Control (2), $n=8$ & $42.13 \pm 12.73$ & $11.25 \pm 1.29$ & $108.13 \pm 18.85$ \\
\hline “Bilobil" (2), 100 mg/kg, n=7 & $34.14 \pm 6.75$ & $11.43 \pm 0.87$ & $128.14 \pm 9.69$ \\
\hline SBRP, 173 mg/kg, n=7 & $98.43 \pm 28.82$ & $7.71 \pm 1.58$ & $93 \pm 20.22$ \\
\hline SBRP, $260 \mathrm{mg} / \mathrm{kg}, \mathrm{n}=7$ & $63.14 \pm 9.04$ & $8 \pm 0.72$ & $102.29 \pm 8.90$ \\
\hline Control (3), $n=6$ & $35.50 \pm 5.81$ & $10.67 \pm 1.36$ & $103.83 \pm 20.6$ \\
\hline “Bilobil" (3), 100 mg/kg, n=6 & $54.00 \pm 13.50$ & $12.67 \pm 1.61$ & $103.67 \pm 16.01$ \\
\hline "Scutex", 320 mg/kg, n=6 & $102.33 \pm 40.18$ & $7.50 \pm 2.55$ & $58.0 \pm 19.04$ \\
\hline Control (4), n=7 & $41.30 \pm 6.13$ & $12.35 \pm 0.98$ & $111.84 \pm 22.6$ \\
\hline “Bilobil" (4), 100 mg/kg, n=6 & $52.22 \pm 10.11$ & $12.71 \pm 1.25$ & $101.22 \pm 17.5$ \\
\hline “Scutella”, 260 mg/kg, n=6 & $55.42 \pm 12.05$ & $9.13 \pm 1.18$ & $104.17 \pm 19.04$ \\
\hline
\end{tabular}

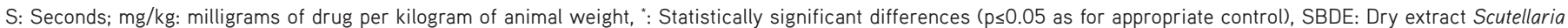
baicalensis, SBRP: Powder of roots and rhizomes from Scutellaria baicalensis

Table 2. The impact of Scutellaria baicalensis drugs and reference drug "Bilobil" on physical endurance of mice by swimming with load test

\begin{tabular}{ll} 
Group, dose, $\mathrm{n}$ & $\begin{array}{l}\text { Time of swimming to } \\
\text { exhaustion, min }\end{array}$ \\
\hline Control (1) & $3.44 \pm 0.33$ \\
\hline SBDE, $50 \mathrm{mg} / \mathrm{kg}$ & $3.41 \pm 0.34$ \\
\hline “Bilobil” (1), $100 \mathrm{mg} / \mathrm{kg}$ & $3.40 \pm 0.27$ \\
\hline Control (2) & $6.01 \pm 0.50$ \\
\hline SBRP, $173 \mathrm{mg} / \mathrm{kg}$ & $7.92 \pm 0.91$ \\
\hline SBRP, $260 \mathrm{mg} / \mathrm{kg}$ & $6.73 \pm 0.75$ \\
\hline “Bilobil” (2), $100 \mathrm{mg} / \mathrm{kg}$ & $6.05 \pm 0.42$ \\
\hline Control (3) & $3.60 \pm 0.23$ \\
\hline “Scutex” $320 \mathrm{mg} / \mathrm{kg}$ & $3.64 \pm 0.20$ \\
\hline “Bilobil” (3), $100 \mathrm{mg} \mathrm{kg}$ & $3.68 \pm 0.43$ \\
\hline Control (4) & $5.81 \pm 0.52$ \\
\hline Scutella, 260 mg/kg & $6.15 \pm 0.56$ \\
\hline “Bilobil” 100 mg/kg & $6.26 \pm 0.42$ \\
\hline
\end{tabular}

All values are meantstandard deviations of six experiments, SBDE: Dry extract Scutellaria baicalensis, SBRP: Powder of roots and rhizomes from Scutellaria baicalensis
Table 3. Impact of dry extract Scutellaria baicalensis, powder of roots and rhizomes from Scutellaria baicalensis, "Scutex", "Scutella" and "Bilobil" on life expectancy in mice under normobaric hypoxic hypoxia with hypercapnia

\begin{tabular}{ll}
\hline Group, dose, $\mathrm{n}$ & Life span, min \\
\hline Control (1), $\mathrm{n}=8$ & $24.47 \pm 1.67$ \\
\hline SBDE, $50 \mathrm{mg} / \mathrm{kg}, \mathrm{n}=8$ & $32.03 \pm 2.18^{*}$ \\
\hline “Bilobil” (1), $100 \mathrm{mg} / \mathrm{kg}, \mathrm{n}=6$ & $30.07 \pm 4.14$ \\
\hline Control (2), $\mathrm{n}=8$ & $23.62 \pm 1.11$ \\
\hline SBRP, $173 \mathrm{mg} / \mathrm{kg}, \mathrm{n}=6$ & $30.87 \pm 3.17^{*}$ \\
\hline SBRP, $260 \mathrm{mg} / \mathrm{kg}, \mathrm{n}=7$ & $38.73 \pm 3.79^{*}$ \\
\hline “Bilobil” (2), $100 \mathrm{mg} / \mathrm{kg}, \mathrm{n}=7$ & $30.96 \pm 1.49^{*}$ \\
\hline Control (3), n=6 & $17.89 \pm 0.60$ \\
\hline “Scutex” 320 mg/kg, n=6 & $21.81 \pm 2.36$ \\
\hline “Bilobil”, 100 mg/kg, n=5 & $20.27 \pm 1.06$ \\
\hline Control (4), n=7 & $22.77 \pm 0.84^{*}$ \\
\hline Scutella, 260 mg/kg, n=6 & $36.99 \pm 3.98$ \\
\hline “Bilobil” (4), 100 mg/kg, n=6 & $29.96 \pm 1.31^{*}$ \\
\hline
\end{tabular}

$\mathrm{mg} / \mathrm{kg}$ : milligrams of drug per kilogram of animal weight. All values are mean \pm standard deviations; number of experiments for each group is mentioned win the table, "Significant differences from control indicator of corresponding series of experiments $(p<0.05)$, \#Significant differences with the rate of animals treated with "Bilobil" ( $p<0.05)$, in the corresponding series of experiments, SBDE: Dry extract Scutellaria baicalensis, SBRP: Powder of roots and rhizomes from Scutellaria baicalensis 
of $173 \mathrm{mg} / \mathrm{kg}$ significantly increased the life duration of mice by 1.3 times compared with the control. Similar results were observed when the reference drug "Bilobil" was administered. Influenced by SBRP at a dose of $260 \mathrm{mg} / \mathrm{kg}$, the lifespan of the mice increased 1.6 times compared with the controls, which is $33 \%$ more than in the background of SBRP at a dose of $173 \mathrm{mg} /$ $\mathrm{kg}$ (Table 3). Accordingly, SBRP at a dose of $260 \mathrm{mg} / \mathrm{kg}$ has the most significant anti-hypoxic effect in terms of normobaric hypoxic hypoxia with hypercapnia and exceeds the effect of comparison drug, and at a dose of $173 \mathrm{mg} / \mathrm{kg}$ SBRP acts at the level of reference drug. "Scutex" tablets only showed a tendency to increase the life duration of mice by $21.9 \%$ compared with the controls. "Bilobil" also showed a tendency to increase lifespan of mice by $13.3 \%$ as compared with the control group. "Scutella" capsules (Table 3) significantly increased the lifespan of mice by 1.6 times compared with the controls. Under the influence of "Bilobil", there was also an increase in life expectancy of mice of 1.3 times compared with the control group. Thus, we can conclude that "Scutella" revealed anti-hypoxic action and had an advantage over the reference "Bilobil" drug. The antihypoxic effect of the latter was not stable, however, because in different experiments it was revealed either on a statistically significant level or biased.

\section{CONCLUSIONS}

SBDE at a dose $50 \mathrm{mg} / \mathrm{kg}$ shows anti-depressant activity that exceeds the activity of the comparison drug "Bilobil". SBRP at doses of $173 \mathrm{mg} / \mathrm{kg}$ and $260 \mathrm{mg} / \mathrm{kg}$, as well as "Scutex" tablets and "Scutella" capsules have no anti-depressant action. SBDE, SBRP, "Scutex" tablets and "Scutella" capsules have not effect on the physical endurance of mice. SBDE at a dose $50 \mathrm{mg} /$ $\mathrm{kg}$ and SBRP at a dose of $173 \mathrm{mg} / \mathrm{kg}$ and $260 \mathrm{mg} / \mathrm{kg}$ exhibit anti-hypoxic activity exceeding the activity of the reference drug "Bilobil". "Scutex" tablets show no anti-hypoxic action and "Scutella" capsules cause probable anti-hypoxic action that exceeds the effect of the reference drug "Bilobil".
Conflict of Interest: No conflict of interest was declared by the authors.

\section{REFERENCES}

1. Yakovleva GP, Blinova KF. Encyclopedic Dictionary of medicinal plants and products of animal origin. Belodubovskaya GA, Zabinkova NN, eds. St. Petersburg; Utchebnaja kniga; 1999:1-407.

2. Ibrahimova VS. Chinese medicine. Methods of diagnosis and treatment. Pharmaceuticals. Acupuncture therapy. Antares. 1994:426-429.

3. Arnal-Shnebellen B, Goetz P. Encyclopedia of medicinal plants (translated from French). Grassar E, Yunen M, eds. Riderz Daydzhest; 2004:1-352.

4. Shang Y, Zhang H, Cheng J, Miao H, Liu Y, Cao K, Wang H. Flavonoids from Scutellaria baicalensis Georgi are effective to treat cerebral ischemia/reperfusion. Neural Regen Res. 2013;8:514-522.

5. Lu JH, Ardah MT, Durairajan SS, Liu LF, Xie LX, Fong WF, Hasan MY, Huang JD, El-Agnaf OM, Li M. Baicalein inhibits formation of $\alpha$-synuclein oligomers within living cells and prevents $A \beta$ peptide fibrillation and oligomerisation. Chembiochem. 2011;12:615-624.

6. Xiong Z, Jiang B, Wu PF, Tian J, Shi LL, Gu J, Hu ZL, Fu H, Wang F, Chen JG. Antidepressant effects of a plant-derived flavonoid baicalein involving extracellular signal-regulated kinases cascade. Biol Pharm Bull. 2011;34:253-259.

7. Slipchenko GD, Shtrygol SY, Kudina OV, Taran AV, Ruban OA. The comparative pre-clinical study of psychotropic properties of the medicines from Scutellaria baicalensis Georgi. Pharmacology and Drug Toxycology. 2016;4-5:41-49.

8. Shtrygol SY, Slipchenko GD, Kudinov AV, Matviichuk AV, Ruban OA. Comparative clinical trials of antiamnestic properties of Scutellaria baicalensis drugs. Phitoterapiya Chasopis. 2016;4:17-20.

9. Tsyvunin VV, Shtrygol SY, Prokopenko YS. Neuroprotective properties of dry extracts of Fumaria schleicheri and Ocimum basilicum. Reviews on clinical pharmacology and Drug Therapy. 2013;11:66-71.

10. Stefanov OV. Preclinical study of drugs (1st ed). Kyiv; Avitsena; 2001:1528.

11. Mironov AN. Guidance on conducting the preclinical studies of pharmaceuticals. (1st ed) Moscow; Griff \& Co; 2012:1-944. 